\title{
Styles of attachment and acquisition of the Theory of Mind
}

Pompéia Villachan-Lyra. Universidade Federal Rural de Pernambuco.

Eliana Almeida. Núcleo de Avaliação Neuropsicológica e Acompanhamento Psicoterapêutico.

Izabel Hazin. Universidade Federal do Rio Grande do Norte.

Samantha Maranhão. Universidade Federal do Rio Grande do Norte.

\begin{abstract}
The goal of the present study was to investigate the possible relationship between the theory of mind and mother-child attachment. Two research questions were asked: (1) At what age does a child show the ability to understand and infer the mental states of others? (2) Is there a systematic relationship between "styles of attachment" and "acquisition of the theory of mind"? Forty children from two age groups (3- and 4-year-olds) participated in the study. For each child, two tasks of false belief (FB) and a task of uncompleted attachment stories were applied. The results indicated a positive correlation between the secure attachment style and good performance on the FB tasks.
\end{abstract}

Keywords: theory of mind, attachment, child development.

\section{Resumo}

Estilos de apego e aquisição da teoria da mente. O objetivo do presente estudo foi investigar possíveis relações entre a teoria da mente e apego mãe-criança. Foram propostas duas questões de pesquisa: (1) a partir de que idade uma criança mostra-se capaz de compreender e inferir acerca de estados mentais e comportamentos de outras pessoas? e (2) pode ser estabelecida alguma relação sistemática entre "estilo de apego" e "aquisição da teoria da mente"? 40 crianças, subdivididas em dois grupos (3 e 4 anos de idade) participaram do presente estudo. Para cada criança, foram aplicadas duas tarefas de crença falsa (CF) e uma tarefa de histórias de apego incompletas. Foram realizadas análises de cunho quantitativo e qualitativo. Os resultados encontrados apontam para uma correlação positiva entre o estilo de apego seguro e o bom desempenho nas tarefas de CF.

Palavras-chave: teoria da mente; apego; desenvolvimento infantil.

\section{Resumen}

Estilos de apego y adquisición de la teoría de la mente. El objetivo de este estudio fue investigar las posibles relaciones entre la teoría de la mente y el apego madre-bebé. Fueron propuestas dos preguntas de investigación: (1) ¿a qué edad un niño presenta la capacidad de comprender e inferir los estados mentales y los comportamientos de los demás? y (2) ¿Puede establecerse alguna relación sistemática entre el "estilo de apego" y la "adquisición de la teoría de la mente"? 40 niños, divididos en dos grupos según la edad (3 y 4 años) - fueron investigados. Para cada niño, se aplicaron dos tareas de falsa creencia (FC) y una tarea con historias de apego incompletas. Los datos fueron sometidos a análisis cuantitativo y cualitativo. Los resultados señalan una correlación positiva entre el estilo de apego seguro y un buen rendimiento en las tareas de FC.

Palabras clave: teoría de la mente; apego; desarrollo infantil. 
Research suggests that episodes experienced by young children during their first year of life strongly influence their developmental processes. Bowlby (1984) and Ainsworth $(1968,1982)$ argued, for example, that the quality of the first attachment relation that is established between children and mothers is very important and has a decisive influence on both future affective relations and cognitive-social development.

Ainsworth and Wittig (1969) published the first empirical study on styles of attachment in infants between 12-18 months of life. The procedure that was established by these authors was named "strange situation," from which three kinds of attachment could be identified: Group A (Anxious-Avoidant), Group B (Secure), and Group C (Anxious-Ambivalent-Avoidant). Attachment styles that are exhibited by older children (from 2 to 6 years of age) were then proposed by these same authors.

Many aspects of child development benefit from the quality of attachment relations at the beginning of life. Among these aspects, Theory of Mind (ToM) must be highlighted. Since the 1990s and even more recently studies on ToM acquisition have highlighted the importance of investigating this ability during early stages of development (i.e., before 3 years of age). The Theory of Mind (ToM) refers to the ability to infer mental states (e.g., beliefs, desires, intentions, imagination, emotions) that cause actions. An individual with a ToM is able to reflect on the content of his/her own and others' minds. (Beebe et al., 2013; Ensor, Devine, Mark, \& Hughes, 2013; Laranjo, Bernier, Meins, \& Carlson, 2010).

The major purpose of these studies can be defined, on one hand, as an attempt to increase the understanding of the influence of the family background and establishment of social relations on the acquisition of the ability to understand mental states, desires, beliefs, and feelings (Beebe et al., 2013; Ensor et al., 2013; Galende, de Miguél, \& Arranz, 2012, 2012; Laranjo et al., 2010, Lundy, 2012). More specifically, such factors as family size, the number of siblings (e.g., Dykas \& Cassidy, 2011; Jenkins \& Astington, 1996), language and discipline styles (e.g., Galende et al., 2012), and attachment style of the child (Bell, 1970; Laranjo et al., 2010; Meins, 2000; Symons \& Clark, 2000) have been considered relevant for understanding the emergence of the ToM. On the other hand, research also focuses attention on the first signs of expression and development of the ToM.

Children are able to show empathy beginning at an early age, which implies certain knowledge about the emotions of others. However, the ability to abstract the thinking and emotional state of someone based on information given and the absence of the actual occurrence of this event requires the mobilization of complex psychological processes. This finding connects the ToM to the ability to make decisions that are guided by the future (Lázaro \& Ostrosky-Shejet, 2012).

The term "Theory of Mind" was first used in the late 1970s, beginning with experimental studies in the animal cognition field, including the classic study by Premack and Woodruff (1978). This study (entitled "Do chimps have a theory of mind?") questioned whether chimpanzees are able to interpret human behavior and attribute mental states to them and themselves. Despite not reaching a final conclusion in this regard, this study aroused a great curiosity in developmental psychologists about the meaning of having an understanding of the mental states of other people and the possible effects of this understanding on behavioral actions in individuals.

As mentioned above, the ToM is defined as a child's ability to understand that people (both themselves and others) have mental states, including thoughts, beliefs, emotions, and desires. The mental representations of mental states are models of the minds of others (and their own mind) and participate in the planning of behaviors that are to be adopted in interactions with other humans (Tonelli, 2011). In a classic study, Moore and Frye (1990) described and characterized a situation that illustrates what is called the ToM:

Imagine that the following story was told to a child: a boy comes home, sees some chocolates in the cabinet room and then goes to his room. While he is not in the room, his mother arrives and decides to put the chocolate in the refrigerator. After some time, the boy returns to the room and wants to eat chocolate. Where will he look for the chocolate? (p. 1)

These authors argued that the correct answer to this question will only be given if the child knows something about the beliefs of the protagonist of the story. In other words, it will depend on the child having a ToM and be able to predict the behavior of the protagonist, based on the information that the child knows that he has and does not have that the child knows is true.

For many of these studies, the quality of the first relationship of attachment established between a infant and its mother figure has shown great importance and may also influence aspects of its cognitive development 
(e.g. Beebe et al., 2013; Bell, 1970; Dykas \& Cassidy, 2011; Ensor et al., 2013; Izard, 1989; Laranjo et al., 2010; Matas, Arend, \& Sroufe, 1978; Meins, 2000; Paradise \& Curcio, 1974; Sharp et al, 1995; Slade, 1987; Spitz, 1987).

The hypothesis that children's understanding of social events is influenced by the quality of relationships they establish with their caretakers early in life has been the center of attention in the attachment literature. Moreover, increasing interest has been seen in possible correlations between different aspects of socioaffective and cognitive development. Some studies have endorsed this position and ratified the importance of building the secure attachment style in early life and its influence on acquiring the ToM (Ensor et al., 2013; Laranjo et al., 2010; Steele, Steele, Croft, \& Fonagy, 1999; Wilson, Meins, \& Turner, 2000).

Symons and Clark (2000), for example, sought to understand how the quality of this relationship can contribute to the development of understanding false beliefs (FBs) in the preschool period. This is a task in which information is provided that allows the child to infer that the protagonist of a story has a different belief from the reality presented. These authors focused on maternal affective aspects and concluded that both the sensitivity and level of distress of the mother influences the child's performance on FB tasks at 5 years of age. These authors emphasized that these results support the literature, highlighting the importance of the social relations process in general and the parental context in particular for the acquisition of the ToM.

Meins (2000) argued for an intrinsic link between the quality of mother-child attachment during early life and cognitive development. This author added that securely attached children had better performance than insecurely attached children on tasks related to a game of make-believe when helped by the experimenter and benefited from external cues to solve the tasks, culminating in greater "social flexibility."

Still investigating the relationship between styles of attachment and acquisition of the ToM, Meins (2000) concluded that children with secure styles of attachment in infancy have an advantage in understanding the language related to mental states and also the ability to assign mental states, beliefs, and emotions to others.

The results reported by Slade (1987) suggested that mothers of securely attached children tend to actively participate in games with their children. The children also presented greater involvement in a game of make-believe, developed with the mother, and also had greater ease in understanding and inferring mental states.

Laranjo and colleagues investigated in two recent and connected studies 61 e 59 mother-child dyads with children aged 12-26 months and four years, respectively. Other relevant variables in these studies were assessment of maternal mind-mindedness, infant attachment, and child ToM understanding. Infant security of attachment was assessed with the Attachment Q-Sort (AQS) completed by a trained observer, and children's ToM abilities were tested at the last visit when children were 26 months and four years of age. According to results from these studies, data suggest that mothers' use of appropriate mind-related comments specifically during toybased free play at 12 months of age predicted preschoolers' understanding of false belief and visual perspective; this cognitive ability took over earlier perspective-taking abilities. Furthermore, more securely attached boys, but not girls, performed better on a task requiring visual perspective-taking. The similarity of results across the two time points suggests the reliability of associations among mothers' use of mind-related comments during toy-based play, boys' attachment security, and children's subsequent social understanding. The same set of results also suggests that maternal mind-mindedness may be most relevant as predictor to children's social cognition when assessed in toy-based play contexts (Laranjo, Bernier, Meins, \& Carlson 2010; 2014).

The studies above mentionned support the position that social and affective experiences that are established by the child in early life in the family context can influence the process of cognitive development. However, none of these studies proposed to specifically investigate the relationship between such experiences and the early acquisition of the ToM in young children (i.e., before the age of 4 years). This was the purpose of the present study.

Characterized as a cross-sectional study, the present study sought to investigate whether children, beginning at the age of 3 years, exhibit evidence of the emergence of the ability to understand and infer the mental states of other people, considering the context of FBs and whether establishing a systematic relationship between the style of attachment and acquisition of the ToM is possible. Recent studies contributes to a greater and better theory of mind understanding at children, but are few studies in the Brazilian Northeast. Based on these objectives, the methodological procedures adopted for this investigation follow. 


\section{Method}

The study included 40 children (20 three-yearolds [11 females and nine males] and 20 4-year-olds [10 males and 10 females]). All of the children were students in a private school in the city of Recife in northeastern Brazil. The choice of these age groups was based on the following: (i) several studies have indicated that 4-yearold children can demonstrate the ability to understand FBs, feelings, and emotions (Freeman \& Laconée, 1995), (ii) some studies have discussed whether, under certain conditions, the development of this ability may occur at an earlier time in child development (Jenkins \& Astington, 1996.), and (iii) the attachment theory adopted in the present study highlights that the spoken indication of emotional links with early attachment figures can only occur beginning at 3 years of age, considering the different dimensions of development that are involved in establishing such relationships (cognitive, affective, and behavioral. Thus, in the present study, 3- and 4-year-old age groups are presented as interesting periods for research on the relationship between styles of attachment and the acquisition of the ToM.

A task of incomplete stories of attachment and two FB tasks were applied. These tasks were individually applied, beginning with incomplete stories of attachment followed by two ToM tasks. All of the tasks were applied in a single session, lasting an average of 20 minutes, in a quiet, air-conditioned room that contained a small table, two small chairs (one for the researcher and one for the child), and a family of puppets that represented the father, the mother, the grandmother, the grandfather, and two brothers. Although two brothers were used in every story, there were four dolls that represented children because, according to the statement offered for the implementation of this task, two siblings of the same sex as the subject must be used, one major and one minor. There were toys that represented a birthday cake, a small table, four chairs, plates and cups (comprising a dining table), a bed with a blanket and a pillow, and a stone.

The research setting and material chosen were inspired by the original procedure adopted by Bretherton, Ridgeway and Cassidy (1990). These authors developed a task of "incomplete attachment stories" that sought to investigate 3-year-old children narratives. This procedure intended to classify attachment based on analyzing children's answers regarding themes previously chosen by the researchers. Notably, the children are involved in creating their narratives in this procedure. Similar to the "strange situation" technique, we sought to identify individual differences in mental representations (i.e., internal working models) of events related to attachment. Bretherton et al. (1990) elaborated a system for classifying this task, based on narrative content and the level of involvement of children when elaborating their narratives to indicate the attachment style of each child.

However, we needed to change a procedural aspect of the study. A small toy car was used to contextualize withdrawal and return stories, but this toy was taken away during a pilot session because it became a distractor for some of the male subjects.

\section{Application procedure and analysis of incomplete stories of attachment}

After entering the room, the researcher asked the child to sit beside her in front of the table. After a moment of casual conversation (to establish a pleasant atmosphere between the child and researcher), the researcher organized the table and chairs for herself and the child and brought in the puppets that represented a family. The researcher then presented each of the family-member puppets and invited the child to help her create stories about that family. She told the child that she will begin telling the story at the beginning, and the child should continue. This task covered the construction of stories related to five themes in everyday situations. The themes were the following:

1. Child spills the juice. While the family is sitting at the table at dinner time, the youngest child accidentally spills juice on the floor, and the mother complains (Problem: the attachment figure is in a place of authority over the child).

2. Monster in the room. After the youngest child has gone to her bedroom to sleep, she complains that there is a monster in her room (Problem: fear that may cause protective behavior).

3. Pitch. The parents leave for an overnight trip and leave the grandmother to take care of the two children (Problem: separation anxiety and ability to deal with situations of pitch).

4. Return. The grandmother looks out the window the next morning and says to the child that her parents are returning (Problem: resistance or disorganized behavior of return). 
5. Child hurts a knee. While the family is walking in the park, the youngest child climbs on a rock, falls, and hurts his knee, and he cries (Problem: pain may cause protective behavior).

The children had to complete each story, which was then evaluated later using a standardized analysis protocol (Bretherton et al., 1990). In each of these stories, a problematic situation that involved the child's relationship with the mother figure elicits a context that enables an analysis of the quality of this relationship and inferences about the quality of child attachment.

In some instances, the researcher helped the child in the task of completing the story. Such assistance could be provided in three ways, either verbally or by manipulating the puppets: (i) asking questions that encouraged the child to tell the story (e.g., "What did they do with the spilled juice?"), (ii) clarifying the child's speech when it was ambiguous or confusing (e.g., "Who put the Band-Aid on John?"), and (iii) asking the child to better develop the story (e.g., "Anything else?" or "How so?").

The analysis of the stories constructed by each child was performed by observing the video records. Each record was thoroughly evaluated by two independent observers. The following aspects were constituted as the focus of the analysis: narrative of the child, emotional components presented by the child (e.g., time to initiate the response, restlessness, facial expressions, tone of voice, posture, smiles, etc.), movement of the family of puppets, and emotional components assigned by the child to each of the characters (e.g., aggression, anger, sadness, joy, gentle and loving behavior, etc.).

The classification of each story of attachment followed the criteria proposed by Bretherton et al. (1990) and was based on structure and content. Initially, each of the five stories was classified as secure or insecure. For this classification, the following aspects were considered: coherence of the narrative constructed by the child, verbal fluency, general affective tone expressed by the child (positive or negative), ability to give a conclusion to the story, and the child's ability to understand the proposed theme of the story.

After classifying the five stories, the protocol for each child was analyzed as a whole, with the objective of classifying the tendency of attachment presented by the child as insecure, secure, or strongly secure. Insecure attachment was assigned to children who had three or more stories that were characteristic of an insecure attachment style. Secure attachment was assigned to children who had three or four stories that were characteristic of safe and secure attachment styles. Strongly secure attachment was assigned to children who had five stories that were characteristic of a secure attachment style.

Notably, even based on the aforementioned criteria, a qualitative clinical analysis was required at the time of analyzing the stories of attachment. Thus, disagreements between the independent observers were discussed until they reached a consensus regarding the classification. If no consensus was reached with the two observers, then a third observer evaluated the videos.

\section{Application procedure and analysis of the false belief tasks}

To investigate the ToM, two classic FB tasks were used: Sally and Anna Task and Smarties Task, both created by Wimmer and Parmer (1983). Some adjustments were necessary to make the tasks more appropriate for our sample. For example, the tasks were called the Mary Task and Chocolate Task, respectively.

The Mary Task allowed an investigation of both the child's acquisition of the ToM and the child's ability to understand and infer the emotional states of others. The material for this task included two rag puppets (with different sizes and clothes), a box with a lid, a toy trunk, and a ring. The application procedure involved the following:

1. Presentation of the material to the child. The child was told, "This is Mary [the largest puppet was presented to the child], and this is Anna [the smallest puppet was presented to the child]. This trunk and this ring belong to Mary, and this box belongs to Anna."

2. Control questions. The child was then asked, "What is the name of this doll? [pointing to Mary] And this other? [pointing to Anna] Whose trunk is this? And this little box? And whose ring is this?" The task was continued only if the child correctly answered all of these questions.

3. Problem situation: The researcher told a problem situation to the child, manipulating the puppets and objects: "Mary and Anna are sisters and go to school together. Mary 
takes her ring and puts it inside her trunk. [the researcher opens the trunk, puts the ring inside, and closes it] and then takes the trunk to school. Anna takes her box. [the researcher moves the puppets, each one holding its object] When they arrive at school, Mary leaves her trunk and goes out to play. [the researcher removes the Mary puppet from the visual field of the child] While Mary is out there playing, Anna opens Mary's trunk and changes the place of the ring, taking it out of Mary's trunk and placing it in her own box, Anna's box [the researcher moves the Anna puppet toward the trunk, opens it, removes the ring inside, opens Anna's box, places the ring inside, and closes the box] Then, Anna also goes out to play. [the researcher removes the Anna puppet from the child's visual field] After a while, Mary comes back and wants to play with her ring. [the researcher returns the Mary puppet to the child's visual field, placing it between the box and trunk]." Throughout the narrative of the problem situation, the researcher ensures that the child paid attention to what was told.

4. Study questions: After the problem situation, the following study questions were asked: "Where will Mary search for her ring?"; "What will Mary feel after searching for her ring in this place?"; "Where really is Mary's ring?".

Just as in the Mary Task, the Chocolate Task was also applied. At the school where the study was conducted, the sale of chewing gum was not permitted in the canteen because the students are very small children. Therefore, a box of chocolate was chosen for this task because this was a sweet sold in the school's canteen and seemed to be a more familiar to the children. The week before implementing this task, at the request of the researcher, the teachers of the classes that would be investigated inserted a box of chocolate into the daily activities of the classroom to ensure that the children formed an association between the box and chocolate. Upon implementing the task, crayons were placed inside the chocolate box, rather than inside a gum box as proposed by the original task.

In this task, the Mary puppet from the previous task was also used. The procedure was the following:
1. Presentation of the material to the child. The researcher showed a typical chocolate box that was closed.

2. Control questions. The researcher then asked, "What do you think is inside this box?" The task continued only when the child responded correctly to this question. After the child's response, the researcher asked the child to open the box and say what is inside it. The child opened the box and said there are crayons.

3. Problem situation: The researcher told a problem situation to the child, manipulating the puppet when relevant. "Do you remember Mary? [the researcher showed the Mary puppet to the child] Mary will come and see this closed box. Mary has not seen what is inside the box. She will come and see the closed box." Once again, the researcher ensured that the child paid attention to what was told during the narration of the problem situation.

4. Study questions: The child was then asked:

- "What will Mary think is inside the box?" (question concerning FB)

- "What seems to be inside the box when we see it closed?" (question regarding the understanding of appearance)

- "What is really inside this box?"

- "Do you remember when I asked you what was inside the box before we opened it? What did you think was inside the box before we opened it?" (question regarding the understanding of change of representation).

Following the study questions, the experimenter showed the child another box of chocolates and asked her to open it and choose some. With that, the construction records sections was finished. This last time was included only for the purpose of thanking the child's participation in the proposed activity.

Similar to what occurred in the incomplete stories of attachment, the analysis of the FB tasks was performed based on observing the video records. The answers given by the children were analyzed based on theoretical references that classified their ratings as appropriate (right) or inappropriate (wrong) for understanding FBs. 


\section{Why use two false belief tasks to investigate the acquisition of theory of mind?}

These two tasks were chosen among the available tasks in the literature concerning investigations of the ToM for the following reasons: (i) both tasks are very frequently utilized in studies that assess the ToM acquisition process, and (ii) these tasks are available in translated versions and utilized in Brazilian studies (e.g., Roazzi \& Santana, 1999). Importantly, the Mary and Chocolate Tasks were created to measure different abilities, although both tasks are related to FBs.

In the Mary Task, the child was asked, "Where is Mary going to look for her ring?" This question sought to evaluate the child's ability to think from the perspective of another person (Mary), considering that Mary did not see her ring being moved and inferring that Mary would look for her ring (based on a FB attributed to Mary by the child).

In the Chocolate Task, the child was asked: "What will Mary think is inside the box?" Similar to the previous task, this question evaluated the child's ability to think from the perspective of another person (Mary), considering that Mary does not really know about the actual content of the chocolate box (crayons) and proposing that Mary is going to think there is chocolate in the chocolate box (based on a FB attributed to Mary by the child). There is, however, a difference between these two tasks. When asked what Mary would think is inside the box, the child needs to understand the meaning of the verbal form to correctly answer the question, attributing thinking content to Mary that differs from the child's (i.e., the child knows there are crayons inside the chocolate box).

Notably, these two tasks investigate FBs. The Mary Task investigates the ability to infer behavior, whereas the Chocolate Task investigates the ability to infer mental states (i.e., a certain thinking content). Therefore, these two tasks investigate different nuances of the ToM construct.

\section{Results}

The present study sought to contribute to discussions of the role of affective mother-child relationships in the emergence of understanding mental states. More specifically, we investigated the existence of a systematic relationship between attachment style and acquisition of the ToM.
The data presented herein were analyzed using Statistical Package for Social Sciences version 10.0 software. The following statistical tests were performed: nonparametric Kendall's Tau-B (W) correlations and multiple-regression analysis.

Considering the children's performance on the Mary Task, $50 \%$ of the 3-year-olds demonstrated an understanding of the FB task. This percentage increased to $77.80 \%$ in the 4 -year-olds, when, in addition to understanding, these children also began to respond better to this task. Although the percentage increased, this difference was not statistically significant $\left(\chi^{2}=2.06\right.$, $\mathrm{df}=1, p=.151$ ).

The next step in the analysis was to evaluate the relationship between the emergence of the ToM and styles of attachment in mother-child relationships. In the Mary Task, 3-year-olds with a strongly secure style of attachment had better performances compared with children with secure and insecure styles of attachment (83.33\%, 50\%, and $28.57 \%$, respectively). Similar results were found in the group of 4-year-old children (100\%, $71.42 \%$, and $50 \%$, respectively) and when the analysis considered the two age groups together $(92.30 \%$, $61.53 \%$, and $36.36 \%$, respectively). A systematic correlation was found between the two age groups (3 years: $\tau=.423, p=.021 ; 4$ years: $\tau=.443, p=.022 ; 3+$ 4 years: $\tau=.446, p=.001$ ).

In the Chocolate Task, the best performance in the 3-year-old age group was observed in the children with a secure attachment style. In this age group and in the 4-year-old and $3+4$-year-old age groups, we found a systematic correlation between performance on this FB task and the style of attachment. The best performance was found with the strongly secure and secure attachment styles ( 3 years: $\tau=.428, p=.017 ; 4$ years: $\tau=.448, p=.013 ; 3+4$ years: $\tau=.437, p=.001$ ).

The nonparametric correlation analysis revealed a significant relationship between performance in these FB tasks and the general style of attachment in 3- and 4-year-old children. Similar results were found when the frequency of appropriate and inappropriate responses in the two FB tasks were analyzed, without considering age as a variable. A significant relationship was found between the secure and strongly secure attachment styles and better performance on both the Mary Task and Chocolate Task.

Considering the children's performance on the two FB tasks together as a single variable, a positive correlation was found between the strongly secure 
style of attachment and better performance. A more detailed inspection of the data indicated that the percentage of inappropriate responses in the two FB tasks decreased and the percentage of appropriate responses increased according to the style of attachment displayed by the 3-year-old children. Also in the 3-yearolds, the percentage of appropriate responses was $0 \%$ in insecurely attached children, which increased to $50 \%$ in children who were secure and strongly secure. The correlation between these two variables was significant $(\tau=.52, p=.009)$. In 4-year-old children, the percentage of appropriate responses in the two FB tasks was not appreciably different between the insecure and secure styles of attachment. For the strongly secure style of attachment, $100 \%$ of the children responded appropriately.

However, the results of the present study also indicated that 3-year-old children, even those who were securely attached, had difficulty understanding the Chocolate Task (50\% correct) compared with 4-yearold children, which scored $100 \%$ correct. This contrasts with the Mary Task, in which $83.33 \%$ and $100 \%$ of the 3- and 4-year-old children made appropriate responses, respectively. What can explain this large difference in the children's performance between the two tasks? As mentioned above, although these two tasks both investigate FBs, the Mary Task more specifically investigated the child's ability to infer the behavior of others, whereas the Chocolate Task investigated the attribution of mental states (more specifically, thinking) in others. Thus, the Chocolate Task may be more difficult for children to comprehend.

\section{Discussion}

With regard to understanding and inferring the mental states of other people, the results of the present study suggest differences based on both age and the general style of attachment displayed by the child. Thus, both 3- and 4-year-old children appear to benefit from the characteristic quality of a secure attachment relationship.

Investigating other aspects of cognitive development, some classic studies in the literature also suggest that relationships between affective aspects (in this case, the quality of attachment relationships) benefit various cognitive skills at different ages. These studies corroborate the present results. For example, Bell (1970) and Paradise and Curcio (1974) investigated the relationship between development of the concepts of object permanence and people permanence and the quality of attachment relationships in children up to 2 years of age. Matas et al. (1978) and Frankel and Bates (1990) investigated the relationship between styles of attachment and problem solving in children between 2 and 3 years of age. Meins (2000) studied 4-year-old children, and Tamis-LeMonda and Bornstein (1994) studied 13- to 20-month-old infants, with a focus on language acquisition.

One controversy that is apparent in the literature is the moment at which the emergence of the acquisition of the ToM occurs. Many authors argue that understanding mental states is possible only beginning at 4 years of age when the child shows the capacity to adopt a conceptual perspective and infer mental states, beliefs, and behaviors of others (e.g., Baron-Cohen, Leslie, \& Frith, 1986; Ruffman \& Olson, 1989.). However, an increasing body of theories defends the opposite position, in which the acquisition of the ToM occurs at an earlier time, around 3 years of age (e.g., Laranjo et al., 2010; Meins, 2000; Symons \& Clark, 2000; Wilson et al., 2000).

Several skills seem to attest to the emergence of the ToM during child development. Infants usually have shared visual attention, reflected by demonstrating a particular interest in faces, particularly the eyes and gaze direction of others. Around 18 months of life, the child usually smiles in response to a smile or verbalizations from others. This speaks to joint attention, also known as shared attention (i.e., the ability to share with others an object or event), outlining the ability to build objectivedirected mental representations (Baron-Cohen, 1995).

Hutchins, Prelock and Bonazinga (2012) cataloged clinical features of the ToM for each period of child development. Early stages were linked to shared attention, followed by the stage of "belief" (i.e., when the child becomes able to differentiate the real from the make-believe, allowing access to imagination and symbolism).

Thus, agreeing with Roazzi and Santana (1999), universality in the time point at which the ability to understand and infer mental states in others develops is liable to be questioned. This aspect requires further investigation to better understand the relationships between the acquisition of this cognitive ability and aspects related to the context in which the child is located, focusing, for example, on the socioaffective relations that are established. 
The present data support the idea defended by the second group of researchers mentioned above (e.g., Laranjo et al., 2010, among others) and suggest that an understanding of mental states can already be observed at 3 years of age. Importantly, however, the acquisition of this skill during this period of development was shown to be directly related to the style of attachment displayed by the child. Insecurely attached children did not show good performance in the FB tasks (28\% in the Mary Task and 0\% in the Chocolate Task) compared with securely attached children (50\% in the Mary Task and $66.7 \%$ in the Chocolate Task) and strongly secure children $(83.3 \%$ in the Mary Task and $50 \%$ in the Chocolate Task).

These data elicit discussions of the role of early socioaffective relationships and contextual aspects in neurodevelopment. Research has shown that the transition from 3 to 4 years of age is accompanied by the emergence of executive abilities, particularly inhibitory control. This capability allows the child to inhibit information from his own or real perspective and understand what happens to the emotional states of others.

According to Joseph and Tager-Flusberg (2004), operational memory and inhibitory control may mediate, or at least provide the conditions necessary for, the successful development of the ToM. This perspective gains strength when appropriate responses in the FB tasks are scrutinized, in which the individual is able to maintain a false representation of a given state in working memory and also able to resist the normal tendency to ascribe mental states from a predominant reality.

Working memory maintains a mental representation and simultaneously coordinates multiple representations in a temporary storage system. In turn, inhibitory control inhibits other representations to maintain a flexible course of action that adapts to the circumstances. Thus, affective aspects can be hypothesized to favor the early maturation of white matter in frontal brain regions in the right hemisphere, thus favoring the early acquisition of the ToM.

Therefore, an important issue is the explanation for this better performance in children with secure attachment. Basing on the theory of attachment (Bowlby, 1984) and some studies that have been based on this theoretical framework, the following aspects should be highlighted.

First, maternal sensitivity during moments of interactions with a child appears to play an important role in the acquisition of the ToM. The regularity and quality presented by the attachment figure (e.g., mother) during times of taking care of the child provides the child the same time information about who his parents are, where they can be found, and how they respond to his needs (which would traditionally be conceived in Attachment Theory as internal models of operation). Over time, the construction of such parameters provides information to the child about his feelings about each of his parents relative to himself, how he believes that each of his parents will treat him, and how to plan his own behavior toward them and others who surround him. Thus, the feelings of comfort and safety that arise from securely attached relationships provides the child with a level of independence and autonomy that allows him to explore the environment, knowing that this mother figure will be available and provide comfort and support during times of danger, thus allowing restoration of the affective bond.

These exploratory behaviors are important for successful adaptation to the demands of the environment and development of social and cognitive skills, thus contributing to establishment of the child's individual characteristics, such as sensitivity and initiative (Steele et al., 1999). Autonomy and safety, based on the establishment of secure attachment, can give the child greater confidence in himself and encourage him to be more daring in exploratory activities, thus offering a greater understanding of his physical and social environment.

With this greater autonomy and self-confidence and the maternal presence as a secure base, securely attached children may also feel more motivated and inclined to establish new social relations because they tend to conceive of these kinds of relationships as positive and encouraging. Thus, these children may have greater ease in establishing and maintaining social relationships. This can promote an understanding of the mental states of others because such experiences with social others favor the initial differentiation between the concepts of "self" and "other," allowing attributions of the mental states to oneself and other people.

Supporting this notion that greater ease in establishing social relationships is exhibited by securely attached children, Lutkenhaus, Grossmann and Grossmann (1985) reported that these children, by 3 years of age, settled faster and had more peaceful relations with the experimenters, often taking the initiative to interact with them. Main and Weston (1981) confirmed these findings, 
suggesting that securely attached children, when in the presence of a parent, were more sociable toward a clown who sought to engage the child in various activities. In contrast, insecurely attached children were anxious and apprehensive in the presence of the clown and avoided the establishment of social interactions.

Second, the quality of maternal care is another aspect that may be related to better performance in understanding mental states in securely attached children and refers to the quality of maternal care at moments of interactions with a child. Generally, mothers who have securely attached children are viewed as more cooperative and available to respond to requests made by their children. According to Ainsworth (1982), these mothers are able to adopt the point of view of the child and tend to see their children as independent and active people, respecting their own points of view. This quality, in turn, seems to present itself as an important aspect in the early acquisition of the ToM in these children.

Third, creative imitation is another aspect that deserves emphasis as being consistent with the ideas of Baldwin (Valsiner, 2000). According to this author, the concepts of "self" and "other" are built on mutual interdependence. In other words, understanding the "other" initially occurs based on what is known about the "self," and vice versa. The child gradually begins to understand the distinction between internal mental states and external events. From this perspective, the concept of imitation plays a central role because imitation of the behavior of others allows the experiences to become available to the child. In the words of Bretherton and Beeghly (1982, p. 920), "The child interprets the behavior of others by analogy to their own behaviors and increases its experimental repertoire through the imitation of the other."

According to Bretherton and Beeghly (1982), during this initial stage of differentiation, to understand the behavior of other people, analogies still need to be made with the child's own behavior. Thus, such an understanding occurs through a specific type of imitation, referred to by Baldwin as "persistent imitation." This is understood as a type of constructive experimentation or a process of constantly creating news through the imitation of a model. Unlike a simple copy of the other's behavior, persistent imitation has a creative character. Thus, securely attached children who have mothers who (i) use terms that refer to mental states (Meins, 1997), (ii) view the children as independent and active, and (iii) respect the point of view adopted by the child and assume that such a point of view may be different from their own (Ainsworth, 1982) tend to differentiate the concepts of "self" and "other" and understand terms that refer to mental states earlier than insecurely attached children, whose quality of social interactions does not present such features.

In summary, the present data suggest that before the end of the fourth year of life, children can demonstrate an understanding of mental states and are able to infer the behavior and beliefs of others based on the FBs that the child knows that such people possess. This does not mean that such a skill is fully developed at 3 years of age. Rather, it is believed that the development and improvement of such an understanding will follow its course and be influenced by and in turn influence co-constructed and modified social and affective relationships throughout the development of the child (Villachan-Lyra, Roazzi, \& Garvey, 2009). Understanding mental states at 3 and 4 years of age can be favored by the quality of attachment relationships established by the child with his mother figure. However, the methodology adopted in the present study did not allow a determination of the quality of the motherchild relationship. The attachment style ascribed to the child and attachment relationship between these partners were based on the child's behavior (verbal and nonverbal). Therefore, we suggest that new studies are conducted to further evaluate this relationship and investigate the peculiarities that characterize the mother-child relationship. Micro genetic-procedural analyses could reveal the influence of this relationship on the acquisition of the ToM in natural environments and in daily activities. Finally, there are different paradigms for the assessment of the theory of mind. False belief paradigm is widely used, but other ToM assessment paradigms should be investigated.

\section{References}

Ainsworth, M. D. S. (1968). Object relations, dependency, and attachment: A theoretical review of the infant mother relationship. Child Development, 40, 969-1025.

Ainsworth, M. D. S. (1982). Attachment: retrospect and prospect. In C. M. Parkes \& J. Stevenson-Hinde (Eds.), The place of attachment in human behavior. New York: Basic Books.

Ainsworth, M. D. S., \& Wittig, B. A. (1969). Attachment and exploratory behavior in one-year-olds in a strange situation. In B. M. Foss (Ed.), Determinants of Infant Behavior (Chap. 4, pp. 111-136). London: Methuen.

Baron-Cohen, S. (1995). Mind blindness. Boston, MA: MIT Press/ Bradford Books. 
Baron-Cohen, S., Leslie, A. M., \& Frith, U. (1986). Mechanical, behavioral and intentional understanding of picture stories in autistic children. British Journal of Developmental Psychology, 4(2), 113-125. doi: 10.1111/j.2044-835X.1986.tb01003.x

Beebe, B., Markese, S., Bahrick, L., Lachmann, F., Buck, K., Chen, H., ... Jaffe, J. (2013). On knowing and being known in the 4-month origins of disorganizes attachment: An emerging presymbolic theory of mind. In M. Janet \& H. Terrace (Eds.), Agency and Joint Attention (pp. 100-124). New York: Oxford University Press. doi: 10.1093/acp rof:0so/9780199988341.003.0006

Bell., S. M. (1970). The development of the concept of object as related to infant-mother attachment. Child Development, 41(2), 291-311. doi: $10.2307 / 1127033$

Bowlby, J. (1984). Apego e perda. São Paulo: Martins Fontes.

Bretherton, I., \& Beeghly, M. (1982). Talking about internal states: The acquisition of an explicit theory of mind. Developmental Psychology, 18(6), 906-921. doi: 10.1037\%2f\%2f0012-1649.18.6.906

Bretherton, I., Ridgeway, D., \& Cassidy, J. (1990). Assessing internal working models of the attachment relationship: An attachment story completion task for 3-year-olds. In M. D. Greenberg \& E. M. Cummings (Eds.), Attachment in the preschool years: Theory, research, and intervention (pp. 273-310). Chicago: Univ. Chicago Press.

Dykas, M., \& Cassidy, J. (2011). Attachment and the processing of social information across the life span: Theory and evidence. Psychological Bulletin, 137(1), 19-46. doi: 10.1037/a0021367

Ensor, R., Devine, R. T., Marks, A., \& Hughes, C. H. (2014). Mothers' cognitive references to 2 -year-olds predict theory of mind at ages 6 and 10. Child Development, 85(3), 1222-35. doi: 10.1111/ cdev.12186.

Frankel, K. A., \& Bates, J. E. (1990). Mother-toddler problem solving: Antecedents in attachment, home behavior, and temperament. Child Development, 61(3), 810-819. doi: 10.2307/1130965

Freeman, N. H., \& Laconée, H. (1995). Making explicit 3-year-olds' implicit competence with their own false beliefs. Cognition, 56, 31-60. doi: 10.1016/0010-0277(94)00654-4

Galende, N., Miguél, M. S., \& Arranz, E. (2012). The role of parent's distancing strategies in the development of five-year-old children's theory of mind. Early Child Development and Care, 182(2), 207-220. doi: 10.1080/03004430.2011.553676

Hutchins, T. L., Prelock, P. A., \& Bonazinga, L. (2012). Psychometric evaluation of the Theory of Mind Inventory (ToMI): Psychometric evaluation of the Theory of Mind Inventory (ToMI): A study of typically developing children and children with autism spectrum disorder. Journal of Autism and Developmental Disorders, 42(3), 327-41. doi: 10.1007/s10803-011-1244-7

Izard, C. E. (1989). Studies of the development of emotion-cognition relations. Cognition and Emotion, 3(4), 257-266. doi: 10.1080/02699938908412708

Jenkins, J. M., \& Astington, J. W. (1996). Cognitive factors and family structure associated with theory of mind development in young children. Developmental Psychology, 32(1), 70-78. doi: 10.1037/0012-1649.32.1.70

Joseph, R. M., \& Tager-Flusberg, H. (2004). The relationship of theory of mind and executive functions to symptom type and severity in children with autism. Development and Psychopathology, 16(1), 137-55. doi: $10.1017 \% 2 F S 095457940404444 X$
Laranjo, J., Bernier, A., Meins, E. M., \& Carlson, S. M. (2010). Early manifestations of children's theory of mind: The roles of maternal mind-mindedness and infant security of attachment. Infancy, 15(3), 300-323. doi: 10.1111/j.1532-7078.2009.00014.x

Laranjo, J., Bernier, A., Meins, E. M., \& Carlson, S. M (2014). The roles of maternal mind-mindedness and infant security of attachment in predicting preschoolers' understanding of visual perspective taking and false belief. Journal of Experimental Child Psychology, 125, 48-62. doi: 10.1016/j.jecp.2014.02.005

Lázaro, J., \& Ostrosky-Shejet, F. (2012). Desarrollo neuropsicológico de lobules frontales y funciones ejecutivas. Manual Moderno: México.

Lundy, B. (2012). Paternal and maternal mind-mindedness and preschoolers' theory of mind: The mediating role of interactiona attunement. Social Development, 22(1), 58-74. doi: 10.1111/ sode. 12009

Lutkenhaus, P., Grossmann, K. E., \& Grossmann, K. (1985). Infant-mother attachment at twelve months and style of interaction with a stranger at the age of three years. Child Development, 56(6), 1538-1542. doi: $10.2307 / 1130472$

Main, M., \& Weston, D. (1981). The quality of the toddler's relationship to mother and father: Related to conflict behaviour and the readiness to establish new relationships. Child Development, 52(3), 932-940. doi: $10.2307 / 1129097$

Matas, L., Arent, R. A., \& Sroufe, A. (1978). Continuity of adaptation in second year: The relationship between quality of attachment and later competence. Child development, 49(3), 547-556. doi $10.2307 / 1128221$

Meins, E. (2000). Is maternal cognition a better predictor of preschool development than security of attachment? Proceedings of the British Psychological Society Developmental, Section Annual Conference, University of Bristol.

Moore, C. \& Frye, D. (1990). The acquisition and utility of theories of mind. In D. Frye \& C. Moore (Eds.), Children's theories of mind: Mental States and Social Understanding (pp. 1-14). New Jersey: Library of Congress.

Paradise, E. B., \& Curcio, F. (1974). Relationship of cognitive and affective behaviors to fear of strangers in male infants. Developmental psychology, 10(4), 476-483. doi: 10.1037/h0036601

Premack, D., \& Woodruff, G. (1978). Does the chimpanzee have a theory of mind? Behavioural and Brain Sciences, 4, 515-526. doi: 10.1017/ S0140525X00076512

Roazzi, A., \& Santana, S. M. (1999). Teoria da mente: efeito da idade, do sexo e do uso de atores animados e inanimados na inferência de estados mentais. Revista Psicologia: Reflexão e Crítica, 12(2), 2, 307-330. doi: 10.1590/S0102-79721999000200005

Ruffman, T., \& Olson, D. (1989). Children's ascriptions of knowledge to others. Development Psychology, 25(4), 601-606. doi:10.1037/00121649.25.4.601

Sharp, D., Hay, D. F., Pawlby, S., Schmucker, G., Allen, H., \& Kumar, R. (1995). The impact of postnatal depression on boys' intellectual development. Journal of Child Psychology and Psychiatry, 38(8), 1315-1336. doi: 10.1111/j.1469-7610.1995.tb01666.x

Slade, A. (1987). Quality of attachment and early simbolic play. Developmental Psychology, 23(1), 78-85. doi: 10.1037/0012 1649.23.1.78

Spitz, R. A. (1987). O Primeiro ano de vida. São Paulo: Martins Fontes. 
Steele, H., Steele, M., Croft, C., \& Fonagy, P. (1999). Infant-mother attachment at one tear predicts children's understanding of mixed emotions at six years. Social Development, 8(2), 161-178. doi: 10.1111/1467-9507.00089

Symons, D., \& Clark, S. (2000). A longitudinal study of mother-child relationship and theory of mind in the preschool period. Social Development, 9(1), 1-23. doi: 10.1111/1467-9507.00108

Tamis-LeMonda, C. S., \& Bornstein, M. H. (1994). Specificity in mother-toddler language-play relations across the second year. Developmental psychology, 30(2), 283-292. http://psycnet.apa.org/ doi:10.1037/0012-1649.30.2.283

Tonelli, H. (2011). Autismo, teoria da mente e o papel da cegueira mental na compreensão de transtornos psiquiátricos. Psicologia: Reflexão e Crítica, 24(1), 126-134. doi: 10.1590/S0102-79722011000100015.
Valsiner, J. (2000). Culture and human development: An introduction. London: Sage

Villachan-Lyra, P., Roazzi, A., \& Garvey, A. P. (2009). Emergência da teoria da mente em relações sociais. In M.R. Maluf \& T. Sperb (Eds.), Desenvolvimento sociocognitivo: Estudos brasileiros sobre Teoria da Mente (vol. 1, p. 55-91). São Paulo: Vetor.

Wilson, G., Meins, E., \& Turner, M. (2000). Individual differences in children's very early understanding of mind. Proceedings of the British Psychological Society Developmental, Section Annual Conference, University of Bristol.

Wimmer, H., \& Perner, J. (1983). Beliefs about beliefs: Representation and constraining function of wrong beliefs in young children's understanding of deception. Cognition, 13, 103-128.
Pompéia Villachan-Lyra, Doutora em Psicologia Cognitiva pela Universidade Federal de Pernambuco, é Professora do Departamento de Educação da Universidade Federal Rural de Pernambuco. Endereço para correspondência: Rua Manuel de Medeiros, s/n, Departamento de Educação da Universidade Federal Rural de Pernambuco - UFRPE, Dois Irmãos, Recife-PE - CEP: 52171-900. Telefone: (81) 33206580. E-mail: lyrapomp@gmail.com

Eliana Almeida, Mestre em Psicologia Cognitiva pela Universidade Federal de Pernambuco, é Neuropsicóloga do Núcleo de Avaliação Neuropsicológica e Acompanhamento

Psicoterapêutico - NANAP. E-mail: eligsa.almeida@gmail.com

Izabel Hazin, Doutora em Psicologia Cognitiva pela Universidade Federal de Pernambuco, Pós-Doutorado em Neurociências pela Université René Descartes - Paris V, é Professora do Departamento de Psicologia Universidade Federal do Rio Grande do Norte. E-mail: izabel.hazin@gmail.com

Samantha Maranhão, Mestre em Psicologia pela Universidade Federal do Rio Grande do Norte, é Doutoranda em Psicologia pela Universidade Federal do Rio Grande do Norte. E-mail: samanthamaranhao@yahoo.com.br 